\title{
Socio-economic features of the regions as a fundamental factor in their long-term development
}

\author{
Yaroslav Lavrinenko ${ }^{1,}$, Viktoria Tinyakova ${ }^{2}$, Alexey Kalashnikov ${ }^{3}$ and Arkady Novikov ${ }^{3}$ \\ ${ }^{1}$ Voronezh State Technical University, Moscovskiy prospect, 14, Voronezh, 394026, Russia \\ ${ }^{2}$ Russian state social university, Wilhelm Pieck street, 4, build.1, Moscow, 129226, Russia \\ ${ }^{3}$ Belgorod State University, 85 Pobedy Street, Belgorod, 308015, Russia
}

\begin{abstract}
The features of the regions in the socio-economic terms determine the development of the national economy and the level of citizens' well-being. The paper highlights the features of the regions depending on three areas: budgetary, social, and economic. These areas are analyzed using the example of the Central Federal District of Russia. Based on the results of the analysis, the features of the regions within the Central Federal District of the Russian Federation are determined. In addition, perspective directions for the development of the regions under consideration are presented on the basis of improving statistics, monitoring, increasing the salaryindex, reducing the debt load on the population, developing the digital economy, and improving the system of subsidies. The possibility of avoiding the subsidization of regions through the development of innovation and agriculture is also shown. An author's approach is proposed to determine the characteristics of the region for their future development. The justifying calculations for the applied approach in the framework of the efficiency of the regional economy on the basis of the salaryindex and the determination of the level of competitiveness of the region on the basis of the energy efficiency index are given. The justifying calculation conducted on the basis of the regions of the Central Federal District of the Russian Federation confirms the developed hypotheses.
\end{abstract}

\section{Introduction}

The features of social and economic development of regions is a fundamental factor for the development of Russianregions. The differences of the regions are primarily associated with the vast territories as well as the heterogeneity of the distribution of minerals and industrial territories.

Abroad, popular theories of regional development in the socio-economic aspect were: the econometric model of the spatial lags of Lungen Inn, the theory of random growth of Ellison, Glaser, Holmes, and Stevens, the Myrdal-Hirschman core-periphery model, the Krugman agglomeration theory and others [1].

\footnotetext{
*Corresponding author: yaroslav_lav1@bk.ru
} 
Foreign theories cannot take into account the current state of Russia and the features of socio-economic development. Many Western scientists rank the Russian Federation as a developing country. But Russia cannot blindly apply mechanisms and models for developing countries, since the fundamental features of the economies of modern regions and countries differ from developing countries.

Of course, at the same time with the development of the regional economy in the Soviet Union, economists were concerned with the differences in socio-economic development. Prominent scientists of the past years were Nekrasov N.N., Kozlov L.A., Vasyutin V.F. In addition, in Soviet times there was a lot of discussion regarding the regional economy as an independent science. Some scientists, such as Krotov V.A., Alaev EB, believed that the regional economy should be concerned with the socio-economic development of regions [2].

The problem of most Soviet theories is that they are currently divorced from market realities, when competition for highly skilled labor and investment resources is increasing. In addition, the Soviet scientific works do not take into account subsidized regions, global increasing income inequality, etc.

In modern Russia, more and more attention has recently been paid to the regional economy. Nowadays, Fetisov G.G., Oreshin V.P., Rozanova T.G. are actively engaged in the development of regional economies [3].

It is worth noting that most foreign scientists propose theories of the development of the economy of modern regions, taking into account the ranking of Russia to developing countries. Although some social and economic factors suggest that Russia is a developing country, there are a number of significant differences [4]:

1. Countries with developing economies are characterized by low rates of development of education and training of specialists. In the Russian Federation, these characteristics are comparable with developing countries.

2. In developing countries, the agricultural sector dominates, and the goal of industrialization is set. In addition, the Russian Federation has great innovative capabilities, although it has a large amount of obsolete physical capital.

3. Russia and developing countries have a low standard of living. But Russia possesses basic free public services: medicine, education, public guarantees.

4. Unlike developing countries, there is no problem of population growth and the need to create jobs in the Russian Federation.

5. The next difference is that in terms of the negative dynamics of the qualifications of the population, Russia has a great potential in retraining the population.

The basic hypothesis is that the regional characteristics of socio-economic development, as a fundamental factor for the effective functioning and prospective development of the economies of modern regions, are not sufficiently considered, and the use of foreign and Soviet models do not take into account the features of the regions as a fundamental factor for development and do not develop effective solutions to problems associated with these features.

In determining the features of the regions, it is necessary to take into account not only current indicators or growth indicators, but also initial or fundamental features. If we consider the regions of Siberia, then comparing them with the regions of the Central Federal District on the provision of high-quality roads will be inadequate. The unreasonableness of comparing regions arises from a number of factors: the size of the resident population, natural conditions, and also initial economic conditions. For example, areas with originally developed industry cannot demonstrate constant tangible dynamics of growth. But the regions where the industry was not developed, but where have been significant investments in the economy in recent years, on the contrary, can show a long and constantly increasing dynamics. Therefore, it is necessary to take a more careful approach to assessing the effective functioning and future development of the economies of 
modern regions. Of course, this does not mean that successful regions should stop the development. But regional features should be considered first.

\section{Materials and methods}

fter analyzing the experience of Russian and foreign scientists and identifying a number of disadvantages in approaches to identifying features of the Russian regions, three areas of features of the socio-economic development of regions are considered as a fundamental factor in their future development. The classification is presented in table 1.

Table 1. Classification of features of socio-economic development by spheres.

\begin{tabular}{|l|l|l|}
\hline Budgetary sphere & Social sphere & Economic sphere \\
\hline $\begin{array}{l}\text { Subsidization of the } \\
\text { Russian regions }\end{array}$ & $\begin{array}{l}\text { Income differences by } \\
\text { region }\end{array}$ & $\begin{array}{l}\text { Differentiation of the efficiency } \\
\text { of regional economies }\end{array}$ \\
\hline $\begin{array}{l}\text { Differences in budget } \\
\text { utilization efficiency }\end{array}$ & $\begin{array}{l}\text { Differentiation of population } \\
\text { density }\end{array}$ & $\begin{array}{l}\text { Lack of synergistic effect in the } \\
\text { districts }\end{array}$ \\
\hline $\begin{array}{l}\text { Low level of } \\
\text { digitalization of the } \\
\text { economy }\end{array}$ & $\begin{array}{l}\text { High debt load of the } \\
\text { population }\end{array}$ & $\begin{array}{l}\text { Concentration of economic } \\
\text { activity in the million-plus } \\
\text { cities }\end{array}$ \\
\hline & Housing & $\begin{array}{l}\text { Different level of innovation } \\
\text { development }\end{array}$ \\
\hline & Level of mortgage loans & $\begin{array}{l}\text { Lack of funding for } \\
\text { environmental programs }\end{array}$ \\
\hline & $\begin{array}{l}\text { Low population density with } \\
\text { high level of urbanization }\end{array}$ & $\begin{array}{l}\text { Strong polarization in the } \\
\text { energy efficiency of regions }\end{array}$ \\
\hline & & Different salaries by region \\
\hline
\end{tabular}

Features in the budgetary sphere.

The first feature of the Russian regions is that the absolute majority of the Russianregions are subsidized. There are only 12 non-subsidized regions. There are only three donor regions in Russia now: Moscow, the Khanty-Mansi Autonomous Okrug, and the Yamalo-Nenets Autonomous Okrug. The subsidy takes 6.45 trillion rubles [5].

Besides, in Russia in 2018, regions appeared where external financial management was introduced. This is due to the fact that more than $80 \%$ of all regional incomes went to repay loans. Total debt of the Russian regions at the beginning of 2018 was 2.5 trillion rubles. Of course, the need for subsidies is caused not only by inadequate financial management in the regions but primarily by the unfair distribution of tax revenues, where the federal budget takes most of it away. Further, thefederalauthoritiesaredistributingfundsbyregions.

The second feature of the Russian regions is the different efficiency of the use of budget funds. This may include the imperfection of strategic socio-economic planning in the context of setting goals and setting clear indicators. The Russian budget system needs to improve target indicators [6]. Some of the current indicators are not integral, or the use of integral indicators is difficult due to the complexity of their calculation as well as the lack of initial data.

The third fundamental feature of the economies of the Russian regions is the relatively low level of digitalization of budget management and the economy as a whole. The constant development of IT-technologies provides opportunities for effective control and adjustment of the results of the regional economies. Currently, digitalization, electronic document management is hardly catching on in the regions, despite the efforts of the federal authorities.

Features in the social sphere.

The first fundamental feature is the differing level of real incomes by region. In addition, in Russia, the Gini coefficient is almost not decreasing, but constantly growing. 
Income inequality in the regions has a negative impact on the economy as a whole, activates migration processes, worsens the criminal situation, and decreases the regional attractiveness for life. However, in regions with low salaries, it is possible to actively attract investments, which in the long run will contribute to an increase in income and standard of living.

The second feature is a strong differentiation of population density by region. Regions with a low population density feel a shortage of skilled labor force. This is due to the fact that such regions have a less developed social infrastructure [7]. In addition, the unevenness of the spatial distribution of the population is even more strongly reflected within the regions, where most of the active and able-bodied people are concentrated in the largest cities.

The third feature under consideration is the high debt load of the population. On average, every citizen of Russia owes banks more than 100 thousand rubles. Overdue debt is $5.5 \%$. However, there are a number of regions where the debt exceeds the average. Inthe Republic of Ingushetia, the Karachay-Cherkess Republic, the Republic of Buryatia, and the Republic of Adygea,overdue debt is $23.92 \%, 12.33 \%, 10.89 \%$, and $10.08 \%$, respectively.

The fourth feature is the level of housing, and also the amount of dilapidated and emergency housing stock. A high level of provision of quality housing affects the indicators of a sense of social protection and the level of sustainability of society. The provision of housing affects the birth rate [8]. Nowadays, the average level of housing is 25.2 square meters per person.

The fifth feature or indicator of the region is the level of mortgage loans. The higher this level, the higher the level of construction. In modern cities, construction is a driving force. In addition, if the population buys mortgagedapartments, then the city is attractive for living, has an adequate level of salaries. It should be noted that this indicator is both a consequence and a cause at the same time. Housing sales are moving forward precisely the regional economy.Therefore, the region is becoming more attractive. In a more attractive region, home sales and mortgage loans are increasing.

The sixth feature of the regions is low population density together with a high level of urbanization and population concentration in cities and large regional centers. This feature affects transportation problems. Since the large centers are far away from each other, the need arises to create a transport infrastructure that is loaded only near large centers.

Features in the economic sphere.

The first feature is the strong differentiation of the economic efficiency of regional economies. It is calculated as the ratio of the gross regional product to the total active or employed population in the region [9]. Regions differ in the degree of GRP dynamics per active person. We can distinguish regions with stable, increasing, and descending dynamics.

The second feature of the regional economy is the absence of synergistic effect for regions within one federal district. Strong regions do not have a positive effect on weaker neighbors. This is due to the fact that there are no horizontal links.

The third feature under consideration is that economic activity is concentrated in cities with a population of over one million people. The consequences of such a concentration are that a rarefaction of the economic and social infrastructure occurs outside the cities [10]. Consequently, the probability of prospective development of regions decreases.

The fourth feature is the differences in the innovative development of regions. The Russian Regional Innovation Index (RRII) is used for calculations. The level of differentiation of RRII of the entities is 3.51 times [10]. Besides, this integral index includes several other indicators, which also have a high degree of differentiation. That is, innovation processes and factors affecting them have a greater degree of differentiation.

The fifth feature of socio-economic development is a different attitude to environmental issues. In most regions, especially with low income, budget funds are allocated for the 
environmental issues on a residual basis. However, more and more environmental problems have a negative impact on the good living conditions of citizens in a particular region. Therefore, we have assigned this indicator to the economic sphere, not the social one [11].

The sixth feature was a strong polarization in the energy efficiency of the regions. The Ministry of Energy of the Russian Federation has published a comprehensive energy efficiency index by region.

The seventh feature is the difference in the relative cost of labor and its salary. The study estimated how many rubles in GRP fall on one ruble of salary. When calculating the indicator, we used the gross regional product of each entity.

The general feature of all regions is the scant statistics of municipalities. Often, a region cannot provide statistics due to the fact that municipalities do not carry out effective measures for its collection.

\section{Results}

The specific features of the Central Federal District will be considered in the context of budgetary indicators.

Table 2. Features of indicators of the Central Federal District in the budgetary sector.

\begin{tabular}{|l|c|c|c|c|}
\hline \multicolumn{1}{|c|}{ CFD entity } & $\begin{array}{c}\text { Population, } \\
\text { thousand people }\end{array}$ & $\begin{array}{c}\text { Subsidies in 2018 } \\
\text { rub/person. }\end{array}$ & $\begin{array}{c}\text { Subsidies for 1 } \\
\text { resident, mln. rub }\end{array}$ & $\begin{array}{c}\text { Digital } \\
\text { economy } \\
\text { index }\end{array}$ \\
\hline Belgorod region & 1552.9 & 2370 & 1.53 & 64.51 \\
\hline Bryansk region & 1220.5 & 12810 & 10.50 & 28.36 \\
\hline Vladimir region & 1389.6 & 5580 & 4.02 & 53.87 \\
\hline Voronezh region & 2335.4 & 7010 & 3.00 & 61.57 \\
\hline Ivanovo region & 1023.2 & 11640 & 11.38 & 42.83 \\
\hline Kaluga region & 1014.6 & 270 & 0.27 & 57.53 \\
\hline Kostroma region & 648.2 & 3700 & 5.71 & 28.55 \\
\hline Kursk region & 1122.9 & 3770 & 3.36 & 60.12 \\
\hline Lipetsk region & 1156.2 & 790 & 0.68 & 62.59 \\
\hline Moscow & 12380 & 0 & 0.00 & 70.01 \\
\hline Moscow region & 7423.5 & 0 & 0.00 & 65.61 \\
\hline Orel region & 754.8 & 5730 & 7.59 & 27.85 \\
\hline Ryazan region & 1126.7 & 3470 & 3.08 & 34.88 \\
\hline Smolensk region & 953.2 & 3250 & 3.41 & 39.09 \\
\hline Tambov region & 1040.3 & 9110 & 8.76 & 44.16 \\
\hline Tver region & 1296.8 & 4080 & 3.15 & 31.05 \\
\hline Tula region & 1499.4 & 1850 & 1.23 & 64.38 \\
\hline Yaroslavl region & 1238.7 & 690 & 0.06 & 57.96 \\
\hline
\end{tabular}

We can see that the most subsidized regions are the Ivanovo, Bryansk, Tambov, and Oryol regions. At the same time, two regions do not have subsidies: Moscow and the Moscow region. If we consider the digital economy index as a factor influencing the level of subsidies to regions, then they are weakly correlated with each other. The next sphere is the social sphere of the Central Federal District. Here we consider the level of income, the level of debt load, debt on housing loans. First of all, we note that the debt load was calculated for the number of economically active population. However, a simple calculation of the debt load provides absolute data in the understanding of how much each active resident of a particular entity owes to banks. However, the debt load, taking into account the average monthly salary, shows the relative debt load, i.e. how many salarieseach 
working person need to pay for the debts to the bank. The higher the rate, the higher the debt load and the more dangerous the situation in the region. The highest load is in the Oryol and Ryazan regions, as well as in Kostroma region. The lowest is in the city of Moscow and the Lipetsk region. The range is from 2.33 to 5.32 .

Salaries are correlated with relative debt load, but do not directly affect it. For example, the Vladimir region has the lowest salaries, but its index is 4.08 - this is the 5 th place in terms of the quality of the indicator.

Table 3. Features of indicators of the Central Federal District in the social sphere.

\begin{tabular}{|c|c|c|c|c|c|}
\hline & $\begin{array}{l}\text { Income, } \\
\mathrm{rub} / \mathrm{mon} \\
\text { th. }\end{array}$ & $\begin{array}{c}\text { Housin } \\
\text { g debt }\end{array}$ & $\begin{array}{c}\text { Debts of the } \\
\text { population, million. } \\
\text { rubles }\end{array}$ & $\begin{array}{c}\text { Absolute debt load } \\
\text { on active } \\
\text { population, million } \\
\text { rubles }\end{array}$ & $\begin{array}{l}\text { Relative } \\
\text { debt load in } \\
\text { monthly } \\
\text { salary }\end{array}$ \\
\hline $\begin{array}{l}\text { Belgorod } \\
\text { region }\end{array}$ & 30074 & 33711 & 102056 & 0.129 & 4.05 \\
\hline $\begin{array}{l}\text { Bryansk } \\
\text { region }\end{array}$ & 26402 & 29442 & 70863 & 0.119 & 4.44 \\
\hline $\begin{array}{l}\text { Vladimir } \\
\text { region }\end{array}$ & 23988 & 36041 & 87010 & 0.128 & 4.08 \\
\hline $\begin{array}{l}\text { Voronezh } \\
\text { region }\end{array}$ & 29327 & 65971 & 148816 & 0.130 & 4.17 \\
\hline $\begin{array}{l}\text { Ivanovo } \\
\text { region }\end{array}$ & 24760 & 23486 & 57452 & 0.115 & 4.52 \\
\hline $\begin{array}{l}\text { Kaluga } \\
\text { region }\end{array}$ & 28108 & 42765 & 89589 & 0.169 & 4.48 \\
\hline $\begin{array}{l}\text { Kostroma } \\
\text { region }\end{array}$ & 24745 & 16325 & 39780 & 0.131 & 4.91 \\
\hline $\begin{array}{l}\text { Kursk } \\
\text { region }\end{array}$ & 26425 & 29219 & 75137 & 0.137 & 4.55 \\
\hline $\begin{array}{l}\text { Lipetsk } \\
\text { region }\end{array}$ & 29294 & 28009 & 71164 & 0.125 & 3.83 \\
\hline Moscow & 62532 & 550664 & 1323898 & 0.184 & 2.33 \\
\hline $\begin{array}{l}\text { Moscow } \\
\text { region }\end{array}$ & 41286 & 406412 & 892670 & 0.221 & 4.37 \\
\hline Orel region & 24122 & 20736 & 49037 & 0.142 & 5.32 \\
\hline $\begin{array}{l}\text { Ryazan } \\
\text { region }\end{array}$ & 24789 & 37594 & 81409 & 0.163 & 5.25 \\
\hline $\begin{array}{l}\text { Smolensk } \\
\text { region }\end{array}$ & 25398 & 30400 & 67157 & 0.139 & 4.81 \\
\hline $\begin{array}{l}\text { Tambov } \\
\text { region }\end{array}$ & 25938 & 24295 & 60373 & 0.127 & 4.83 \\
\hline Tver region & 24077 & 42142 & 92094 & 0.141 & 4.66 \\
\hline Tula region & 27774 & 44271 & 113205 & 0.149 & 4.45 \\
\hline $\begin{array}{l}\text { Yaroslavl } \\
\text { region }\end{array}$ & 27625 & 34409 & 83405 & 0.132 & 3.95 \\
\hline
\end{tabular}

First of all, we note that the debt load was calculated for the number of economically active population. However, a simple calculation of the debt load provides absolute data in the understanding of how much each active resident of a particular entity owes to banks. However, the debt load, taking into account the average monthly salary, shows the relative debt load, i.e. how many salarieseach working person need to pay for the debts to the bank. The higher the rate, the higher the debt load and the more dangerous the situation in the region. The highest load is in the Oryol and Ryazan regions, as well as in Kostroma region. The lowest is in the city of Moscow and the Lipetsk region. The range is from 2.33 to 5.32. 
Salaries are correlated with relative debt load, but do not directly affect it. For example, the Vladimir region has the lowest salaries, but its index is 4.08 - this is the 5th place in terms of the quality of the indicator.

Next, we estimate the economic sphere of the entities of the Central Federal District. First, consider the gross regional product. In this case, not only the actual volume was considered, but the volume per one active or working person. This shows the performance of the entity.The more one person contributes to GRP, the higher the overall GRP and relative standard of living. Secondly, we consider the relative level of productivity and labor costs, i.e. the banal price/quality ratio of labor force. Let's select the regions where it is higher.

In the third place, we assess the innovative development in the region on the basis of the Russian Regional Innovation Index. In the fourth place, weassess the environmental development of the regions and the focus on environmental problems by the entities of the Central Federal District.

Table 4. Features of indicators of the Central Federal District in the economic sphere.

\begin{tabular}{|l|r|r|c|c|}
\hline & $\begin{array}{c}\text { GRP, million } \\
\text { rubles }\end{array}$ & $\begin{array}{c}\text { Per one worker, } \\
\text { thousand rubes }\end{array}$ & $\begin{array}{c}\text { Innovation } \\
\text { Development Index } \\
\text { (RRII) }\end{array}$ & $\begin{array}{c}\text { Environmental } \\
\text { index }\end{array}$ \\
\hline Belgorod region & 730562 & 921.56 & 18 & 4 \\
\hline Bryansk region & 285848 & 481.87 & 47 & 81 \\
\hline Vladimir region & 392052 & 577.75 & 43 & 55 \\
\hline Voronezh region & 841376 & 735.83 & 15 & 48 \\
\hline Ivanovo region & 179633 & 358.27 & 57 & 32 \\
\hline Kaluga region & 373404 & 703.52 & 6 & 17 \\
\hline Kostroma region & 160705 & 530.73 & 76 & 29 \\
\hline Kursk region & 364602 & 662.47 & 42 & 50 \\
\hline Lipetsk region & 470239 & 823.45 & 16 & 12 \\
\hline Moscow & 14299801 & 1991.56 & 2 & 82 \\
\hline Moscow region & 3565258 & 882.64 & 14 & 43 \\
\hline Orel region & 213924 & 621.14 & 60 & 26 \\
\hline Ryazan region & 336974 & 676.70 & 45 & 1 \\
\hline Smolensk region & 262318 & 542.45 & 39 & 63 \\
\hline Tambov region & 311433 & 653.27 & 67 & 75 \\
\hline Tver region & 359345 & 550.61 & 32 & 25 \\
\hline Tula region & 517741 & 681.45 & 37 & 28 \\
\hline Yaroslavl region & 469805 & 744.15 & & \\
\hline
\end{tabular}

We will separately consider energy efficiency in the regions of the Central Federal District. Energy efficiency is important in the framework of improving the competitiveness of Russian industrial enterprises. If energy is consumed a lot, then enterprises use outdated technologies and/or equipment. Nowadays, Russian companies often lose to foreign competitors by energy consumption. 


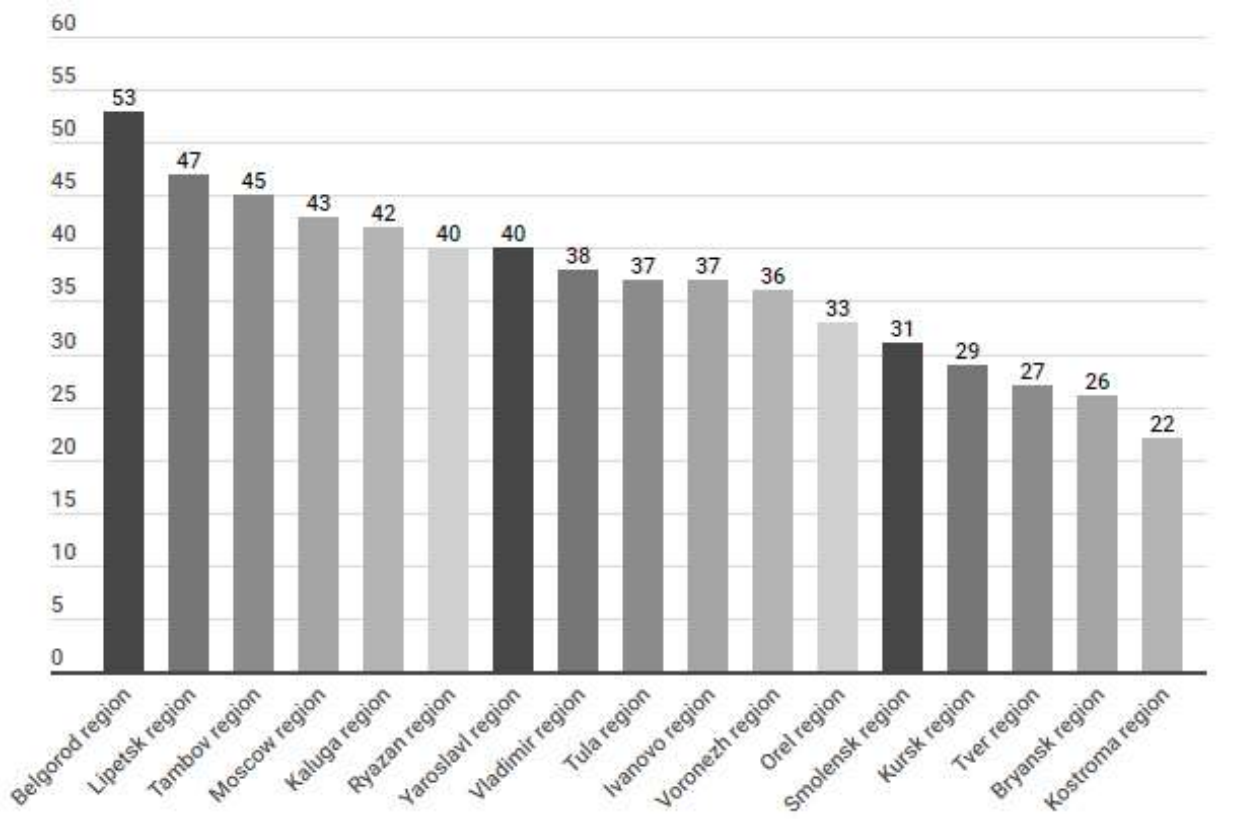

Fig. 1. Energy efficiency of CFD entities.

Assessment of the productivity of the active population was given in Table. 1. However, this is only the absolute productivity of one worker, his contribution to the gross regional product of an individual entity. But the relative productivity becomes interesting: how much salaries are lower than the contribution of a person to the gross regional product. The data are given below in table 5 .

Table 5. Calculation of GRP and salary index.

\begin{tabular}{|l|r|r|c|}
\hline & $\begin{array}{c}\text { GRP per year per } \\
\text { person, thousand rubles }\end{array}$ & $\begin{array}{c}\text { Salary per year per } \\
\text { person, thousand rubles }\end{array}$ & Salary index \\
\hline Belgorod region & 921.56 & 381.88 & 2.41 \\
\hline Lipetsk region & 823.45 & 390.17 & 2.11 \\
\hline Moscow & 1991.56 & 949.81 & 2.10 \\
\hline Tambov region & 653.27 & 314.47 & 2.08 \\
\hline Voronezh region & 735.83 & 374.86 & 1.96 \\
\hline Orel region & 621.14 & 321.28 & 1.93 \\
\hline Yaroslavl region & 744.15 & 401.13 & 1.86 \\
\hline Kursk region & 662.47 & 360.36 & 1.84 \\
\hline Ryazan region & 676.70 & 373.66 & 1.81 \\
\hline Tula region & 681.45 & 401.46 & 1.70 \\
\hline Kostroma region & 530.73 & 320.77 & 1.65 \\
\hline Smolensk region & 542.45 & 346.72 & 1.56 \\
\hline Kaluga region & 703.52 & 452.25 & 1.56 \\
\hline Vladimir region & 577.75 & 377.08 & 1.53 \\
\hline Tver region & 550.61 & 363.33 & 1.52 \\
\hline Bryansk region & 481.87 & 322.71 & 1.49 \\
\hline Moscow region & 882.64 & 606.78 & 1.45 \\
\hline Ivanovo region & 358.27 & 304.37 & 1.18 \\
\hline
\end{tabular}

Salary index: how many times the GRP is higher than the cost of salaries. Here the leader immediately stands out - this is the Belgorod region, and the outsider is the Ivanovo region. 
Let us present a rating of indicators of the entities of the Central Federal District for a more convenient visual comparison.

Table 6. Final rating of the regions of the Central Federal District by indices.

\begin{tabular}{|l|c|c|c|c|c|c|}
\hline & I $_{\text {income }}$ & I $_{\text {GRP }}$ & I $_{\text {salary }}$ & I $_{\text {energy }}$ & $I_{\text {subsidies }}$ & $I_{\text {debt }}$ \\
\hline Moscow & 18 & 18 & 16 & 18 & 18 & 18 \\
\hline Moscow region & 17 & 16 & 2 & 14 & 18 & 12 \\
\hline Belgorod region & 16 & 17 & 18 & 17 & 12 & 15 \\
\hline Voronezh region & 15 & 13 & 14 & 7 & 11 & 13 \\
\hline Lipetsk region & 14 & 15 & 17 & 16 & 14 & 17 \\
\hline Kaluga region & 13 & 12 & 6 & 13 & 15 & 9 \\
\hline Tula region & 12 & 11 & 9 & 9 & 13 & 10 \\
\hline Yaroslavl region & 11 & 14 & 12 & 11 & 16 & 16 \\
\hline Kursk region & 10 & 9 & 11 & 4 & 8 & 7 \\
\hline Bryansk region & 9 & 2 & 3 & 2 & 2 & 11 \\
\hline Tambov region & 8 & 8 & 15 & 15 & 3 & 4 \\
\hline Smolensk region & 7 & 4 & 7 & 5 & 7 & 5 \\
\hline Ryazan region & 6 & 10 & 10 & 12 & 10 & 2 \\
\hline Ivanovo region & 5 & 1 & 1 & 8 & 1 & 8 \\
\hline Kostroma region & 4 & 3 & 8 & 1 & 5 & 3 \\
\hline Orel region & 3 & 7 & 13 & 6 & 4 & 1 \\
\hline Tver region & 2 & 5 & 4 & 3 & 9 & 6 \\
\hline Vladimir region & 1 & 6 & 5 & 10 & 6 & 14 \\
\hline
\end{tabular}

$\mathrm{I}_{\text {income }}-$ the index of the average level of per capita income in the entity. The higher the index, the higher the income.

$\mathrm{I}_{\mathrm{GRP}}-$ the gross regional product per active population. The higher the index, the higher the GRP per person.

$I_{\text {salary }}$ the ratio of GRP per person to the average salary per year. The higher the index, the higher the productivity of the workforce.

$I_{\text {energy }}$-the energy efficiency rating of the entities of the Russian Federation according to the Ministry of Energy of the Russian Federation. The higher the index, the higher the energy efficiency of the region.

$I_{\text {subsidies }}-$ the sum of subsidies to the regional budget, which falls on each resident of the entity. The higher the index, the lower the amount of subsidies per person.

$\mathrm{I}_{\text {debt }}-$ the ratio of the debt to banks per one person to the sum of the average salary in the region. The higher the index, the lower the ratio.

The hypothesis about the need for a different approach to determining the socioeconomic features of the regions as a fundamental factor in their future development is justified by the above calculations on the basis of the Central Federal District.

\section{Discussion}

As part of the conducted calculation on the basis of the regions of the Central Federal District, we will present practical perspective directions for the development of the Central Federal District.

1. Improving the monitoring and statistics system and digitalization of the economy.

Effective functioning and future development of the economy of modern regions is possible only in terms of effective management. Effective management is based on actual statistics. Therefore, first of all, for the effective development of the economy, it is necessary to improve the methodology of socio-economic indicators. The system of indicators must comply with a number of principles: 
- Comprehensive system of indicators. The system and indicators separately should reflect the situation in all areas of the economic and social sphere. And not only those that are directly managed but also mediated. In addition, indicators should be consistent with each other and rely on a single implementation mechanism.

- Quick delivery of up-to-date data. Indicators must be obtained within a calendar year with a certain periodicity and be able to be compared.

- Relatively simple indicators combined with full coverage. Often, when making certain decisions regarding effective functioning and long-term development, there is not enough time for detailed elaboration of indicators. Therefore, indicators should be simple.

- Openness of indicators and socio-economic processes in the region. The openness and availability of indicators in the region create a transparent environment, allowing investors to make more effective decisions about locating production facilities in the region.

- Unambiguous interpretation of indicators. The methodology should be based on the fact that all indicators can be interpreted unambiguously and compared with other indicators.

2. Improving the system of subsidization of regions.

Effective distribution of funds between budgets of different levels is one of the characteristic features of any federative state structure. Nowadays, this system does not have high efficiency, because an adequate system of relations between the center and the regions and further downward has not been established. This situation leads to a decrease in the stability and absolute dependence of the budgets.

The second point is to determine the actual level of development and socio-economic security of each region in the Central Federal District. Such a system of indicators will show the need to smooth out the inequality of subjects within the federation and within the CFD.

The third point is to determine the root causes of high subsidization in most regions with several donor regions. It is worth noting that there are regions whose donation is selfevident: oil producing or industrial regions, as well as our "two capitals": Moscow and St. Petersburg. But there are a number of other regions, such as the Republic of Tatarstan and the Samara region.

3. Gradual withdrawal of the CFD from the system of subsidies.

The regions of the Central Federal District are a storehouse of Russian and world black soil. However, the yield lag behind the world figures. For example, the yield of winter wheat in Germany in the range of 80-90 c/ha, and in the Voronezh region in 2017 - only $40.5 \mathrm{c} / \mathrm{ha}$. However, in Verkhnekhavsky district, a record was set at $101 \mathrm{c} / \mathrm{ha}$. The result is that agriculture can be 2 times more efficient than it is now. Therefore, it is necessary to support those manufacturers who show results above average. In addition, it is necessary to learn from the experience of these farms and teach others by their example.

4. Reducing the debt load.

According to the results of the study, regions with a high share of debt load per working person were identified. The public should be alerted to the need for a thoughtful approach to taking loans and learning financial literacy. High debt load is not only the task of the population itself. Criminogenic conditions, "workers' slavery" due to fear of losing their jobs, etc., grow with high debt load.

5. Development of innovation activity.

According to the RRII index, the regions of the Central Federal District are in the middle of the level of innovation. However, in the CFD, there are 518 public and private institutions of higher education. Here, $31 \%$ of all students or 1.4 million people study, half of them full-time. This is a huge potential both student and post-education. The regions of the Central Federal District should pay more attention to scientific development in collaboration with universities, students, and science. If we analyze the foreign experience, universities are accelerators of the development of entities. 
6. Increase in the salary index in the framework of the GRP.

In our opinion, the salary rate is an indicator that describes how the contribution of one ruble to salary is converted in the contribution of GRP. The highest salary index is recorded in the Belgorod region - 2.41.

7. Improving the energy efficiency of entities.

Regions should pay more attention to reducing the energy consumption of certain industries. Energy efficiency is the key to improving the competitiveness of regions.

\section{Conclusion}

For effective functioning and prospective development of the economies of modern regions, it is necessary to understand regional features in social and economic development. Adequate understanding of the features is a fundamental factor for the effective functioning and development of the regions of Russia. The general features of Russian regions are based on the fact that the country holds an intermediate position between developing and developed countries. On the one hand, there are many similar characteristics with developing countries, such as low income and quality of life. However, it has high social guarantees, a large amount of physical capital, although outdated. Besides, there is no problem of lack of jobs, on the contrary, there is no shortage of specialists of the whole range of qualifications. In addition, negative dynamics of the qualifications of the population istraced, but there is the potential for retraining.

The paperconsidered the features of regional budgets by spheres: budgetary, social, and economic. Using the example of the Central Federal District, the level of regional subsidization, the level of digitalization, real incomes of the population, the differentiation of population density, the level of debt load of the population were analyzed in the budgetary and social sphere. In the economic sphere, we revealed differences in the level of GRP per working person, noted economic hyperactivity in million-plus cities, uneven innovation differences. Salary index in the framework of the GRP per one ruble of costs was estimated. In addition, a strong polarization in the energy efficiency of the regionswas noted, which is one of the key factors in increasing the competitiveness of the regions as a whole.

The hypothesis developed within the new approach to the determination of the socioeconomic features of the regions as a fundamental factor in their prospective development is confirmed by calculations based on the Central Federal District, and the practical directions for the development of the CFD regions are given. For effective development, it is necessary to improve the subsidy policy within the federal structure, the regions of the Central Federal District should move away from subsidy dependence, developing innovative research and agriculture. Quality management should be built on a system of adequate and simple indicators and a monitoring system in conjunction with the development of the digital economy. Besides, energy efficiency is one of the priority areas in the regional economy, which indirectly shows the level of development and organization of production, and also the level of competitiveness of the region as a whole.

\section{References}

1. Yu.A. Gadzhiev, Ekonomikaregiona 2, 45-62 (2009)

2. T.I. Bezdenezhnyh, M.M. Makenov, Regional'naya ekonomika: teoriya I praktika 3(438), 541-552 (2017)

3. I.Ilin, S. Shirokova, A. Lepekhin, E3S Web of Conferences, 33, Article number 03007 (2018) doi:10.1051/e3sconf/20183303007 
4. L.M. Badalov, Strategicheskoe ekologo-ekonomicheskoe razvitie regionov I municipal'nyh obrazovanij v usloviyah globalizacii (Moscow, 2017)

5. A.N. Kalashnikov, Ekonomika ustojchivogo razvitiya 4, 203-210 (2018)

6. V.I. Tinyakova, O.S. Chemeris, Upravlenie gorodom: teoriyaipraktika 3(30), 48-58 (2018)

7. Ilin, O.V. Kalinina, O. Iliashenko, A. Levina, Procedia Engineering, 165, 1673-1682. (2016) doi: 10.1016/j.proeng.2016.11.909

8. Lukmanova, A. Chizhik, A. Fadeev, Y. Lavrinenko, E. Sharapova, MATEC Web of Conferences conference proceedings 01096 (2017)

9. V.I. Tinyakova, I.V. Yurkovskij, A.A. Ziroyan, Ekonomika I predprinimatel'stvo 2(91), 267-273 (2018)

10. T. V. Alesinskaya, D. V. Arutyunova, V. G. Orlova, I. Ilin, S. Shirokova, Conception BSC for investment support of port and industrial complexes. Academy of Strategic Management Journal, 16 (Special issue1), 10-20 (2017)

11. R.D. Hapanceva, Social'nyenauki 5(15), 108-114 (2016) 